\title{
RESEARCH PAPER \\ THE USE OF NATURAL LIGHTING IN STUDENTS' HOSTELS: A CASE STUDY OF AYEDUASE, A SUBURB OF KUMASI, GHANA
}

\author{
C. Koranteng ${ }^{1}$, B. Simons ${ }^{1}$ and J. Nkrumah ${ }^{2}$ \\ ${ }^{1}$ Department of Architecture, KNUST, Kumasi \\ Corresponding E-mail: christiankoranteng@yahoo.co.uk \\ ${ }^{2}$ Development Office, KNUST, Kumasi
}

\begin{abstract}
The role that natural lighting plays in buildings cannot be underestimated. Natural light is integrated into buildings because of its potential economic benefit and the effect on the occupants' psychological and physiological well-being. This study concentrates on Ayeduase, a suburb of Kumasi, Ghana, where students live in hostels with poor architectural design. Therefore, the primary aim of this study is to investigate the health and visual comfort of students living in Ayeduase, by creating awareness of the positive effects of natural light on humans. Questionnaires and interviews, as well as empirical measuring of daylight levels in the spaces of selected hostels were used. Analysed data revealed that the level of illuminance in the hostels is considerably poor and this resulted in students using artificial lighting throughout the day. Nevertheless, the negative effect of this situation can be prevented from occurring in further developments in Ayeduase (and Ghana as a whole), by educating designers on the benefits of using natural lighting in buildings and by enforcing laws that will ensure that buildings have maximum openings that allow enough daylight into the interior spaces. These measures will help reduce utility costs, improve the well-being of building occupants and increase the performance of students.
\end{abstract}

Keywords: Natural Lighting, Building Science, Occupants, Perception

\section{INTRODUCTION}

Light has always been a predominant factor in the activities of mankind. Many efforts have been made to design buildings that use a great percentage of natural light, in both the developed and the developing countries. Large amounts of money, which almost surpass the cost of a building, are used to light up spaces in buildings. In the year 2002, the cost of electricity in Ghana was 6 US cent per kWh (Resource
Centre for Energy Economics and Regulations (RCEER), 2005). However, electricity consumption can be reduced if natural lighting is prioritized in building designs. In actual fact, natural lighting gives a natural view of materials and tends to produce more positive responses than artificial lighting. Edwards and Torcellini (2002) claimed that natural light has psychological and physiological effects on the occupants of a building and as such should be 
considered well when designing. Natural or daylight is also said to most closely match the visual response that through evolution, humans have come to compare with all other light (Franta and Anstead, 2011).

The increasing population of students at the Kwame Nkrumah University of Science and Technology (KNUST) campus has instigated the proliferation of several hostels in the neighbouring communities. Ayeduase, a suburb of Kumasi, provides hostels to an appreciable number of KNUST students. Natural lighting in most of these hostels is nothing to write home about. The result is the use of artificial lighting in the corridors and rooms of these hostels, even when it is a bright sunny day.

As noted by Guzowsky (2010), the presence of daylight in buildings maximizes the architectural potential while increasing human comfort and visual perception. Most of these hostels lack the essential resource which nature offers freely. Openings of these hostels are poorly designed or positioned. It has become a normal practice that lighting in these hostels is achieved only through artificial means. This in actual fact has a negative effect on the performance of students living in such hostels, since lighting has a psychological and physiological influence on the life of an individual. As buttressed by Edwards and Torcellini (2002), on a cloudy day or under poor lighting conditions, the inability to perceive the colours from light can affect our mood and energy level. This invariably, increases accidents, reduces mental performance and as a result, decreases students' academic performance.

This study is aimed at identifying the key operational determinant hindering the use of natural lighting in buildings and how this situation could be improved in Ayeduase students' hostels.

It is hoped that the results of the study will contribute to the general well-being of students and improve upon the quality of buildings being constructed in Ghana.

Since time immemorial, man has sought for ways and means of living comfortably in his environment. Man is a diurnal being who needs good natural light in the day for him to function psychologically and physiologically sound in his environment.

Varying opinions have been published about the physics of light by different writers. A Scottish physicist named James Clerk Maxwell (1831 - 1879) showed that electric and magnetic fields fluctuating together can form a propagating wave, which was named an electromagnetic wave (Serway and Faughn, 2003). Further, light is said to be this type of wave. Maxwell knew that a changing electric field produced a magnetic field. In 1905 Einstein concluded that light is composed of corpuscles, or discontinuous quanta of energy (Serway and Faughn, 2003). Bigelow (2008) says it is the form of radiant energy that stimulates the organs of sight.

Louis Kahn once said: "natural light is the only light that makes architecture architecture" (Egan and Olgway, 1983). The sun releases a power flux of $63 \mathrm{MW}$, equivalent to six thousand million lumens, for every square metre of its surface area. Of this, about 134 kilolux reaches the earth's outer atmosphere. The atmosphere absorbs about $20 \%$ of this light and reflects another $25 \%$ back into outer space. A fraction of the remaining $55 \%$ reaches the ground directly, as sunlight, the rest is first diffused by the atmosphere (skylight) - these two together make up daylight (Stein and Reynolds, 2000). All natural light emanates from the sun, the light entering buildings either being direct light from the sun or reflected light. The illuminance provided by a bright sunny sky may be as much as 100,000 lux, though light of this intensity often causes glare and overheating. The importance of light in architecture has been expressed by Le Corbusier (Jormakka, 2008): "Architecture is the masterly, correct and magnificent play of volumes brought together in 
light". Furthermore, the history of architecture is said to be the history of the struggle for light. Reinhart et al. (2006) did not only have an architectural view of natural lighting, but also saw the need to pinpoint what day lighting does in different aspect of buildings (visual stimuli, lighting energy savings, reduction in building energy savings, minimization of operating costs and the maximization of productivity, etc.).

Natural light has direct and indirect effects on human beings: the direct effects are caused by chemical change in tissues due to the energy of the absorbed light, while the indirect ones concern the regulation of the basic biological functions and the production of hormones, connected to light exposure. Therefore, to improve well-being, satisfaction and productivity, especially in hostel buildings, it is very important to project indoor spaces with specific attention to occupants comfort. A study by West as cited in Heerwagen (2004) found that prison inmates who had various views from their windows, such as vegetation or mountains had lower sick -related cells than the ones who had their windows oriented to the courtyard where noise from passers-by emanated. Natural light is generally known to be a remedy for curing skin diseases. Natural light contains the right amount of UV radiations that the skin needs for its proper functioning. Exposure to UV radiations produces vitamin $\mathrm{D}$ in the skin which is essential for metabolic functions, including the absorption of calcium and phosphorus (Egan and Olgyay, 1983)

Edwards and Torcellini (2002), on the benefits of natural lighting in educational buildings, found that there is increased student and teacher attendance, increased achievement rates, reduced fatigue factors, improved student health, and enhancement of general development. Furthermore, natural lighting eliminates noise and flickering from electric light sources and provides the best quality of light available in classrooms, gymnasiums, and corridors. Their extensive research has also shown that students in windowless classrooms are more hostile, hesitant, and maladjusted. Moreover, students in windowless classrooms tend to be less interested in their work and complain more (Edwards and Torcellini, 2002).

In 2004, Ghanaians consumed 5,158 gigawatthours (GWh) of electricity. It is estimated that about half of this amount is consumed by domestic (or residential) consumers for household uses such as lighting, ironing, refrigerating, air conditioning, television, radio and the like (ECG, 2005). In all, lighting was found to consume more electricity than any other appliances because of poor architectural designs of some houses. Illuminations in these houses are switched on from morning to evening so that spaces could be used for activity. Moreover, the choice of external surfaces near a building can either enhance or detract from the character of illumination within a building. This presupposes that effective landscaping, which will enhance proper reflection, must be ensured, if adequate natural lighting is to be admitted into a building (Heerwagen, 2004). Designing buildings with a natural lighting strategy in mind will definitely ease the burden of electricity costs, improve well-being and increase productivity.

\section{APPROACH}

The lack of adequate accommodation on University campuses in Ghana is a paramount problem students are confronted with. The problem has been somehow ameliorated by inefficient hostel buildings sited in the neighbouring towns of Universities. Students have no choice but to stay in such hostels to continue with their studies. Unfortunately, poor architectural designs of hostels which manifest in the use of artificial lighting throughout the day have invariably reduced the satisfaction of students residing in them. The objective of this paper is to examine the quality of natural lighting in Ayeduase ( $6^{\circ} 40^{\prime} 32^{\prime \prime}$ North, $1^{\circ} 33^{\prime} 44^{\prime \prime}$ West) students' hostels. The town was selected because it has most of the top ranked hostels (considered to shelter about $40 \%$ of students) around the KNUST. Despite the fame that the 


\section{$41 \quad$ Koranteng et al.}

town enjoys, in this respect, natural lighting is a major problem in most of the hostels. In this context, the main objectives of the research study are; (i) to examine how lighting levels affect the occupants of the hostels; (ii) to find out how natural and artificial lighting are used by students; and (iii) to study possible health effects of long-term exposure to poor lighting.

The methods used in this research were questionnaires, interviews, observations and empirical measurements.

The main areas of information needed from the respondents were related to their background, knowledge and possible effects of natural lighting with regards to the physiological and psychological outcome.

Tape measure was used to measure floor areas and building elements (windows) of the buildings. Furthermore, a multi-function environment meter (PCE - 222) was used to measure the illuminance level in three hostels (NAD, HES and GEM). The one month measurement period (March 1 to 31, 2011) resulted in data which was grouped in MS Excel to generate mean values. The values (indoor and outdoor illuminances) were used to calculate the daylight factors of the spaces.

\section{RESULTS AND DISCUSSIONS NAD (Block B) Hostel}

This is a four (4) storey hostel accommodating 48 students and located at the western part of Ayeduase. It has a $1.8 \mathrm{~m}$ high fence wall and the compound is landscaped with pavement bricks. The general layout of the spaces is double-banking (a corridor with a width of $1.8 \mathrm{~m}$, sandwiched between a bank of rooms), and the floor area for each room is $12 \mathrm{~m}^{2}$. The corridors are furnished with brown terrazzo for the floor, cream colour paint for the walls, and white colour paint for the ceiling. All the sleeping spaces have balconies and washrooms (Fig. 1), and the floors are furnished with light terrazzo, cream colour paint on walls and white paint on the ceiling.
The mean outdoor illuminance tabulated was 19,735 lux. The mean illuminance for two rooms ( $\mathrm{F}$ and $\mathrm{I}$ ) on the northern wing of the hostel was 50.7 and 17 lux. The daylight factor (see Equation 1) for the spaces ( $\mathrm{F}$ and $\mathrm{I}$ ) was calculated to be $0.257 \%$ and $0.086 \%$. When a building is designed to rely on day-lighting, a prime design concern is the daylight factor as expressed in Equation 1 (Stein and Reynolds, 2000).

Daylight Factor $(\mathrm{DF})=\mathrm{Ei} /$ Eo $\times 100$

Where $\mathrm{Ei}$ is indoor and Eo outdoor illuminances.

The daylight factor is a relation that is based on how much light is available outdoors; the resultant light indoors will differ with the light outdoors. The target daylight factor for ordinary seeing tasks (reading, filing and easy office work) is $1.5-2.5 \%$ and for moderately difficult tasks (prolonged reading, stenographic work and normal machine tool work) is $2.5-4.0 \%$ (Stein and Reynolds, 2000 and Fischer et al., (2008). The mean daylight factor for the spaces in the southern wing was calculated to be $0.04 \%$. The results illustrate that artificial lighting would be needed, since the DF values were all below the target mean value of $2 \%$ for ordinary seeing tasks (Stein and Reynolds, 2000 and Fischer et al., 2008). This analysis insinuates that it is not the amount of light from the sun that is inadequate, but rather how to get the natural light into the interior of the building. In addition, Hopkinson et al. (1966) outlines that the recommended daylight factors for a living room, a bedroom, and a typing and computing room should not be less than $1 \%, 0.5 \%$ and $4 \%$ respectively. The studied rooms are used as a learning place for students, and as such, the mean daylight factor should not be less than $2 \%$. Herewith, one could conclude that the illuminance levels in the NAD Hostel rooms are poor and that natural lighting strategies are not well utilized.

\section{HES Hostel}

This facility is a four storey hostel located 


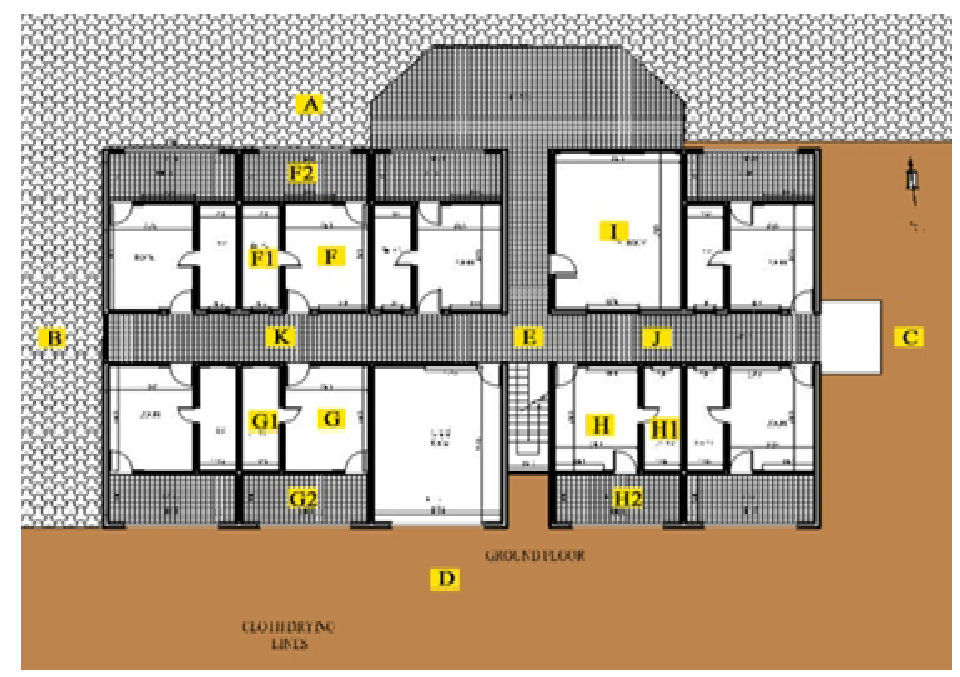

Fig. 1: Schematic floor plan of NAD hostel (block B) showing measurement locations

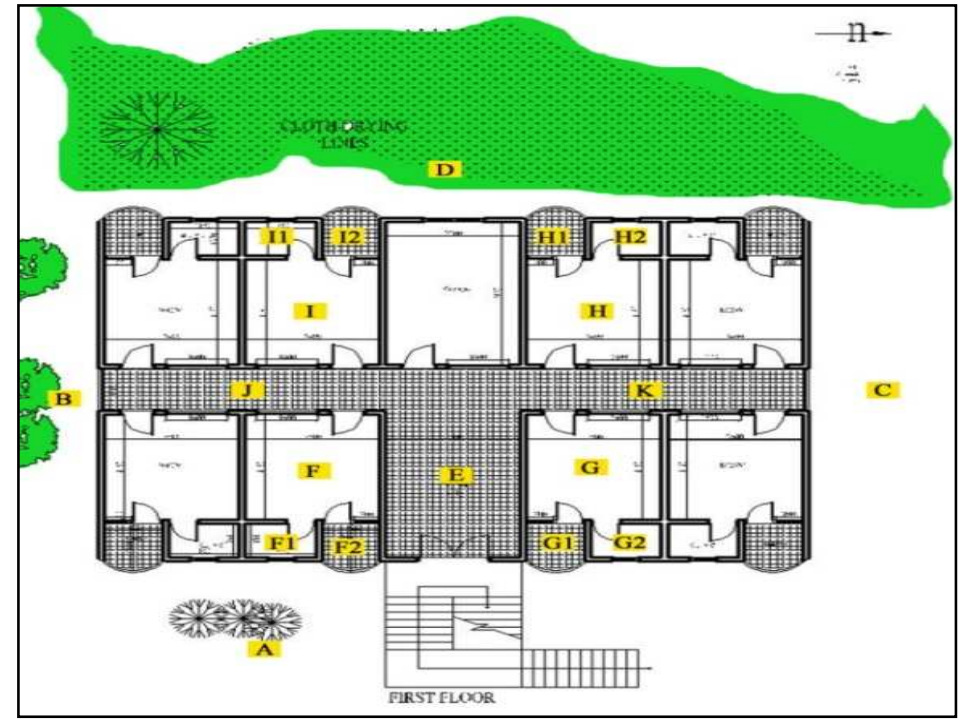

Fig. 2: A conceptual floor plan of HES hostel showing positions where measurements were taken

beside the Ayeduase-Kotei road on the eastern side of Ayeduase. It is a double bank hostel with a $1.7 \mathrm{~m}$ corridor width and a $14.53 \mathrm{~m}^{2}$ floor area for each room. The corridors are furnished with polished light brown tiles on the floor, brown paint on the walls and white paint for the ceilings. Each room has a balcony, a washroom and the floors are furnished with polished white tiles, light brown paint for the walls and white paint for the ceilings. Two window walls with a size of $9.3 \mathrm{~m}^{2}$ each are located opposite of each other, with window sizes of $2.4 \mathrm{~m}^{2}$ and $1.1 \mathrm{~m}^{2}$ 


\section{Koranteng et al.}

respectively, with the bigger one leading into the corridor and the smaller one oriented towards the balcony (see Fig. 2).

To obtain a general knowledge on the illuminance in the Hydes hostel, the western and the eastern part of the hostel were studied. The western part has the annotations of 'I' and ' $\mathrm{H}$ ' while the eastern part has the annotations of ' $F$ ' and ' $G$ '. Considering the western side of the hostel during the morning period (8:00-10:00 hrs.), the internal spaces (I and $\mathrm{H}$ ) and the outdoor space (D) recorded 6.15 lux, 3.5 lux and 3340 lux respectively. Hence, the daylight factor at "I" and " $\mathrm{H}$ " could be calculated as $0.184 \%$ and $0.104 \%$.

Consequently, the afternoon period recorded daylight factors of $0.035 \%$ for "I" and $0.038 \%$ for " $H$ ". At hours 16:00 to 18:00, the daylight factor for "I" recorded $0.321 \%$ while " $\mathrm{H}$ " recorded $0.154 \%$. The illuminance levels at the eastern part of the hostel were different. Daylight factors of $0.059 \%$ to $0.330 \%$ were tabulated for "F" and "G" respectively. These illuminance values are low when compared to the recommended levels (Heerwagen, 2004; Stein and Reynolds, 2000; and Hopkinson et al., 1966). This was partly due to the smaller window to wall ratios of the external walls (less than 20\%) (Ruck, 2001). The light brown paint also has a lower reflectance value and thereby reducing the total illuminance of the interior spaces (Gary and Steffy, 1990). The use of white coloured paints (70-90\% reflectance) would help improve upon the quality of the spaces (Egan and Olgyay, 1983).

\section{GEM Hostel}

This is a three storey hostel accommodating 105 students and located on the western side of Ayeduase. The GEM hostel has a small courtyard in the middle of the facility. Finishes for the corridor are polished brown tiles for the floors, brown colour paint for the walls and white colour paint for the ceilings. The finishes for the rooms are polished yellow tiles for the floors, yellow paint for the walls and white paint for the ceilings. The hostel has a $1.55 \mathrm{~m}$ corridor width and a $14.3 \mathrm{~m}^{2}$ floor area for each room. The two window walls have size $9.6 \mathrm{~m}^{2}$, with window sizes of $2.3 \mathrm{~m}^{2}$ and $1.2 \mathrm{~m}^{2}$, with the larger window directed towards the corridor and courtyard (Figs. 3 and 4).

The illuminance and daylight factors result on the northern part (annotated F and D) and the southern part (annotated $\mathrm{G}$ and $\mathrm{A}$ ) are elaborated. In the mornings (8:00 - 10:00 hrs.), the readings at " $F$ " (room) on the northern side of the hostel recorded 1.6 lux, while the area marked "D" (outdoor) recorded 1307.5 lux. Hence the daylight factor at " $F$ " could be calculated as $0.122 \%$.

The mean illuminance at the room recorded in the afternoon (12:00 -14:00 hrs.) produced a daylight factor of $0.487 \%$. At the same area, the illuminance reading in the evening (16:00 18:00 hrs.) produced a daylight factor of $0.044 \%$. The southern part of the hostel was also reviewed in terms of its illuminance. However, the poor pattern of low illuminance values continued. The reasons were that the window to wall ratios are low (less than $25 \%$ as against 60 - $80 \%$ for an efficient performance (Koranteng, 2011a), the colour of the interior walls (yellow) absorbs more light, the inefficient courtyard in getting the daylight to the rooms by virtue of its small size, the use of curtains or shades, etc. (Koranteng, 2011b and Koranteng and Mahdavi, 2010).

\section{Questionnaire and Interview results (all buildings)}

Questionnaires were distributed to 30 students to ascertain their views on natural light in their hostels. The number of students interacted with comes with challenges (adequate sample size) in studying small population sizes (Nwana, 1992). Nevertheless, the students' views give an indication of the perception and behaviour in hostels, which could help improve upon the quality of buildings in general.

Some of the results of the interviews are out 


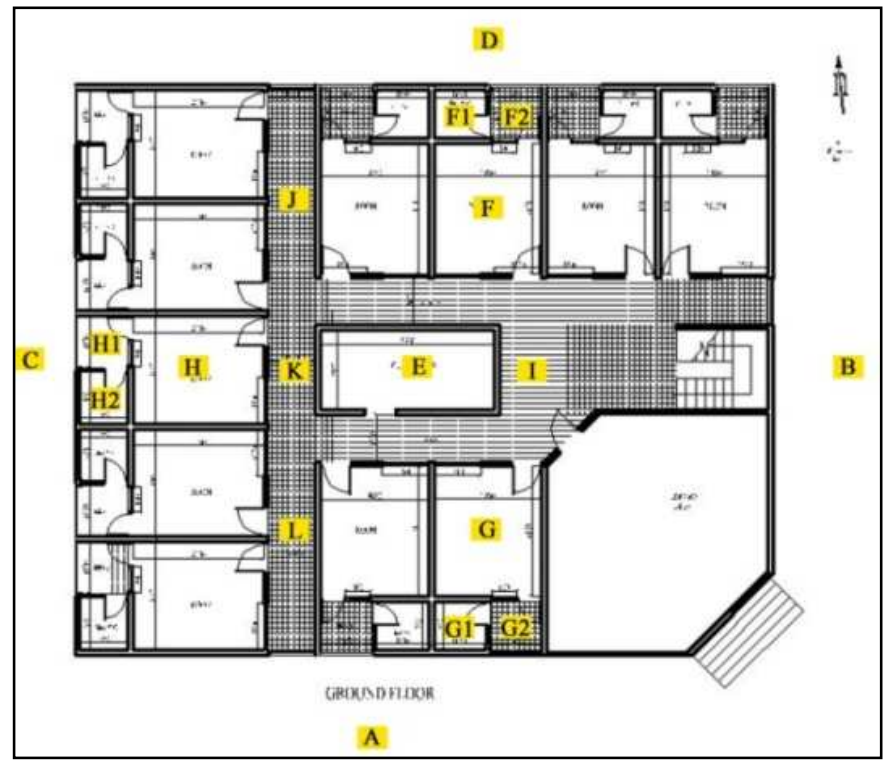

Fig. 3: A schematic plan of HES hostel showing points where illuminance was measured

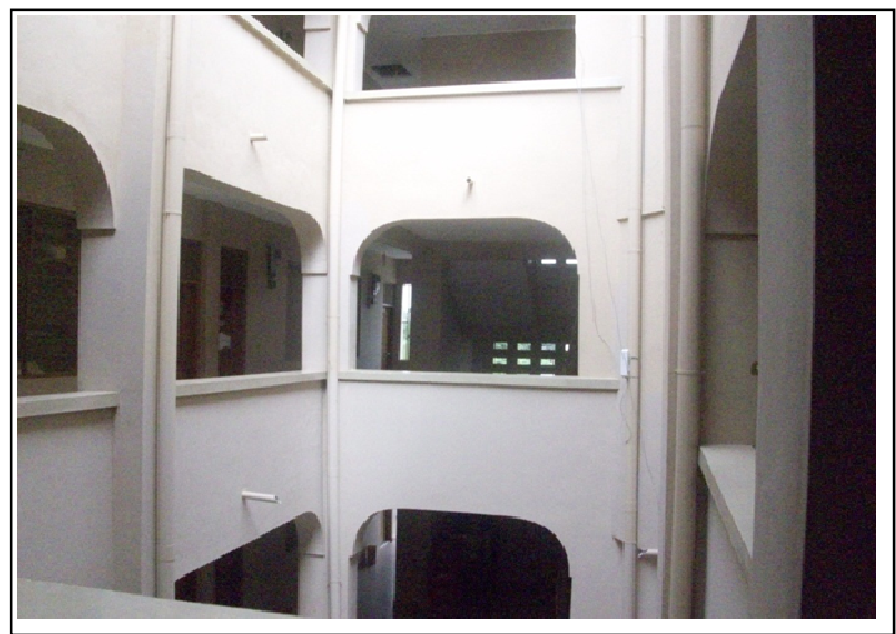

Fig. 4: A view showing the inefficient courtyard of the HES hostel

lined and discussed. On the activity the students most frequently carried out in the hostels, fifteen $(50 \%)$ out of the thirty students chose reading and writing by hand, while twelve students chose working with the computer. Furthermore, twenty-four out of the thirty students said that they studied more in their rooms
(Fig. 5).

Knowledge about the use of lighting (natural or artificial) in the hostels revealed that $95 \%$ of the respondents made use of artificial lighting throughout the day (Fig. 6). This is understandable since the measured illuminances were 


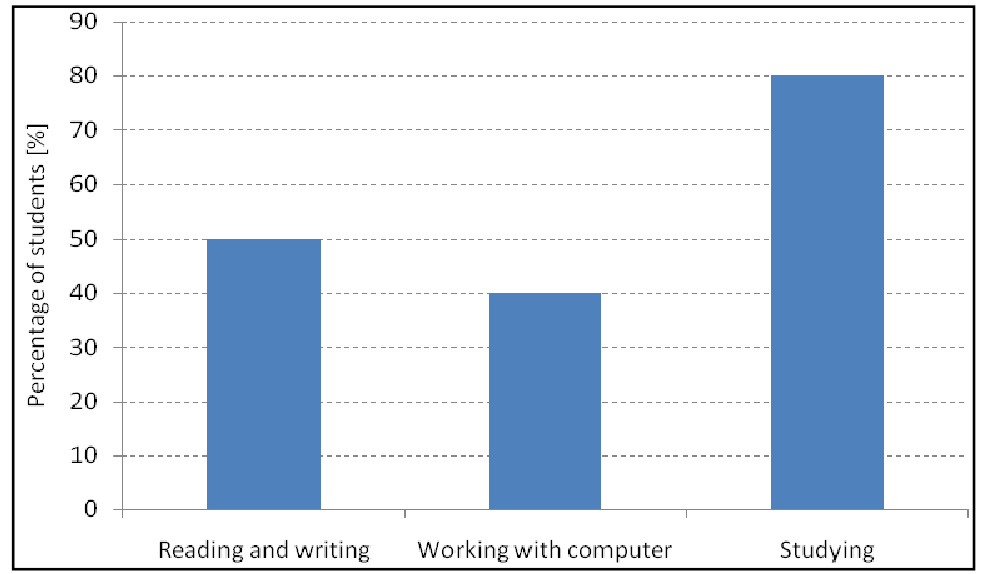

Fig. 5: Activity students most frequently carried out in the hostels

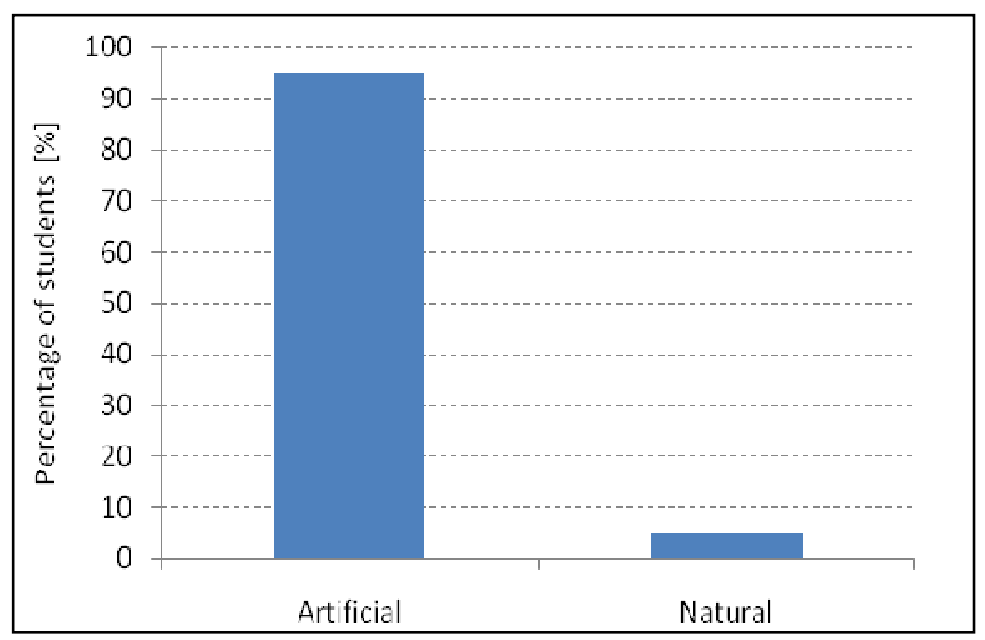

Fig. 6: Mode of lighting used by students during the day

really low. Illuminance levels of 400 to 500 lux are recommended for desktop activities (reading and writing) (Stein and Reynolds, 2000).

The health complaints (headache, eyestrain and itching, etc.) by $40 \%$ of the respondents can also be linked to the low illuminance levels within the spaces.

Questions regarding user behaviour (the opera- tion of windows and shades to bring in natural light) resulted in over $70 \%$ of the students saying that they were able to operate the windows and use the shades (curtains) to improve upon their visual comfort. Rooms that are oriented towards the east and west could be observed to have the curtains in place to block direct and reflected solar radiation. This practice however, has the consequence that occupants then resort to the use of artificial lighting which is known to have negative implications on energy consu- 
mption (Koranteng, 2009; Mahdavi et al., 2007; Sutter et al., 2006; and, Nicol and Roaf, 2005). The impact of switching on the light 'all the time' was mostly felt by students who had to bear the cost of their consumed electricity.

\section{CONCLUSIONS}

The study had the objective of evaluating natural light in students' hostels. This was because of the often poor architectural designs that are created for students to use as hostels, without considering the use of sustainable design principles and occupants comfort. The study was based on empirical measurements and questionnaires. Data gathered and analysed showed mean daylight factors of $0.03 \%$ to $0.5 \%$ as against (the recommended factor of $2 \%$ ). The low values were as a result of low window to wall ratios $(25 \%)$ and low reflectance value of colours used in the hostels. Moreover, $80 \%$ of the students studied in their rooms and $95 \%$ of the interviewees made use of artificial lighting during the day. The number of students who had diverse health complaints (headache, eyestrain and itching, etc.) was $40 \%$. The poor illuminance levels in the spaces can also be linked to the use of curtains by the students. Curtains remained retracted even when there was no disturbance from direct and reflected solar radiation. The three studied hostels did not perform well because of the poor architectural designs.

\section{RECOMMENDATIONS}

To alleviate the deteriorating effect of bad lighting conditions in hostels, the following should be considered:

- Training of architects and draughtsmen on the use of natural lighting design principles;

- Students should be taught to understand that it is more important to allow natural light into a space than to decorate the room with curtains;

- The education of students and landlords (hostel owners) about the positive effects and benefits when natural lighting is used in spaces;
- The rolling-up of window curtains especially in the afternoons as an effective means to allow light to penetrate into a space should be enhanced.

- Strict policies on having surface finishes of high reflectance should be enforced in all the hostels in Ayeduase;

- Natural lighting should be made the prior means of lighting hostels in the day by institutionalizing strict policies which oblige designers of hostels to adhere to the use of recommendations for sizing windows, the use of materials with high reflectance values and the use of sustainable design principles; and

- More technological means could include the use of light tunnels for every room and mechanized window curtains that roll up automatically to allow natural light into spaces.

These measures when applied could help improve upon the comfort of students, their wellbeing and help reduce energy consumption of buildings.

\section{ACKNOWLEDGEMENT}

The authors acknowledge the immense contributions of Mr. ABOSOMPIM Kobina Baiedu (Department of Architecture, Kwame Nkrumah University of Science and Technology) and the owners of the studied hostels for their assistance towards this study.

\section{REFERENCES}

Bigelow, L. (2008). Light and its Effects on Living Matter, American society for Photobiology, Photochemistry and Photobiology, 61(5): 1-110.

ECG (2005). Energy Commission Ghana. National Energy Statistics pp. $25-50$.

Edwards, L. and Torcellini, P. (2002). A Literature Review of the Effects of Natural Light on Building Occupants E-book, Available at: scribd.com, Accessed: April 2011. 
Egan, M. and Olgyay, W. (1983). Architectural Lighting, McGraw-Hills, New York.

Fischer, H., Freymuth, H., Haeupl, P., Homann, M., Jeninsch, R., Richter, E. and Stoehrer, M. (2008). Theory of Building Physics, Vieweg and Taubner Verlag, Germany.

Franta, G. and Anstead, K. (2011). Daylight, Human Health and Performance, DCS 558: Spring 2011, www.public.asu.edu/.../ Daylight\%20and\%20Human\%20Health.pdf, Accessed: May 2011.

Gary, R. and Steffy. (1990). Architectural lighting Design, Van Nostrand Reinhyold Company, New York.

Guzowski, M. (2010). Daylight Strategies for Sustainable Schools: Case Study of Prototype Classrooms in Libya, Journal of Sustainable Development, 3 (3): 60-68.

Heerwagen, D. (2004). Passive and Active Environmental Controls, McGraw-Hills, New York.

Hopkinson, R. G., Petherbridge, P. and Longmore, J. (1966). Daylighting, The Pitman Press, Bath, Britain.

Jormakka, K. (2008). Basics: Methoden der Formfindung, Birkhaeuser Verlag AG, Berlin.

Koranteng, C. (2011a). The Thermal Performance of an Educational Office Building in Ghana, Journal of Applied Science and Research, 3(4): 222-232

Koranteng, C. (2011b). A Thermal Comfort Evaluation in Low-Rise Office Buildings in Ghana, Journal of Applied Science and Research, 3(5): 165-178.

Koranteng, C. (2009). An Evaluation of the thermal. Performance of Office Buildings in Ghana, Institute of Building Physics and Hu- man Ecology, Technology University of Vienna.

Koranteng, C. and Mahdavi, A. (2010). An Inquiry into the Thermal Performance of Five Office Buildings in Ghana, 10th Rehva World Congress, Sustainable Energy Use in Buildings, CLIMA 2010, Antalya, Turkey, May 9 - 12, 2010.

Mahdavi, A., Orehounig, K., and Mikats, N. (2007). Analyzing Traditional Buildings via Empirically Calibrated Building Performance Models. Proceedings of IBPSA 2007 (10th International Building Performance Simulation Association Conference and Exhibition. Beijing, China, 3-6 September 2007), ISBN 0 -9771706-2-4, pp. 71-78.

Nicol, F. and Roaf, S. (2005). Post-Occupancy Evaluation and Field Studies of Thermal Comfort, Building Research and Information, 33(4): $338-349$.

Nwana, O. C. (1992). Introduction to Educational Research, Ibadan, Nigeria, Heineman Educational Books.

RCEER (2005). Guide to Electric Power in Ghana, Institute of Statistical and Economic Research, University of Ghana.

Reinhart C. F., Mardaljevic, J. and Rogers, Z. (2006). Dynamic Daylight Performance Metrics for Sustainable Building Design, Archives of National Research Council Canada, Leukos, 3(1): 1-25, www.nrc-cnrc.gc.ca/obj/ $\mathrm{irc/doc/pubs/nrcc48669/nrcc48669.pdf,} \mathrm{Ac-}$ cessed: June 2011.

Ruck, N. (2001). Daylight of Buildings, Environment Design Guide, www.mfe.govt.nz/ publications/.../passive-solar-design-guidance .pdf, Accessed: April 2011.

Serway R. A. and Faughn, J. S. (2003). College Physics, $7^{\text {th }}$ Edition, www.mediafire.com/? ihiv4cwigge93d4.pdf, Accessed: May 2011. 
Use of natural lighting in students' hostels... 48

Stein, B. and Reynolds, J. S. (2000). Mechani- Sutter, Y., Dumortier, D. and Fontoynont, M. cal and Electrical Equipment for Buildings, Ninth Edition, John Wiley \& Sons, Inc., New York, USA, pp. 455-475. (2006). The Use of Shading Systems in VDU Task Offices: A Pilot Study, Energy and Buildings, 38(7): $780-789$. 